\title{
ANALISIS TINGKAT KEPUASAN PASIEN RAWAT INAP RUMAH SAKIT BANGLI MEDIKA CANTI DITINJAU DARI KUALITAS PELAYANAN
}

\author{
Ni Kadek Suci Ariska ${ }^{1}$ \\ Made Mulia Handayani ${ }^{2}$ \\ ${ }^{1}$ Fakultas Ekonomi Universitas Ngurah Rai, Bali, Indonesia \\ e-mail : sucikim94@gmail.com \\ ${ }^{2}$ Fakultas Ekonomi Universitas Ngurah Rai, Bali, Indonesia
}

\begin{abstract}
ABSTRAK
Penelitian ini bertujuan untuk mengetahui tingkat kepuasan pasien rawat inap Rumah Sakit Bangli Medika Canti ditinjau dari kualitas pelayanan dan untuk mengetahui atribut yang menjadi prioritas untuk diperbaiki pada pasien rawat inap Rumah Sakit Bangli Medika Canti. Jumlah sampel ditentukan dengan Rumus Slovin sebanyak 98 pasien rawat inap pada Rumah Sakit Bangli Medika Canti. Data dianalisis dengan menggunakan metode Customer Satisfaction Index (CSI) dan Importance-Performance-Analysis (IPA). Hasil penelitian menunjukkan bahwa tingkat kepuasan pasien rawat inap Rumah Sakit Bangli Medika Canti berada pada kriteria puas dan atribut yang menjadi prioritas untuk diperbaiki adalah atribut fasilitas penunjang pada pasien rawat inap Rumah Sakit Bangli Medika Canti.
\end{abstract}

Kata kunci : Kualitas Pelayanan, Kepuasan Konsumen dan Rumah Sakit

\section{ABSTRACT}

This study aims to determine the level of satisfaction of inpatients at Bangli Medika Canti Hospital in terms of service quality and to identify priority attributes to be improved in inpatients at Bangli Medika Canti Hospital. The number of samples was determined by Slovin Formula as many as 98 inpatients at Bangli Medika Canti Hospital. Data were analyzed using the Customer Satisfaction Index (CSI) and Importance-PerformanceAnalysis (IPA) methods. The results showed that the level of satisfaction of inpatients at Bangli Medika Canti Hospital was in satisfied criteria and priority attributes to be improved were attributes of supporting facilities in inpatients of Bangli Medika Canti Hospital.

Keywords: Service Quality, Customer Satisfaction and Hospital 


\section{PENDAHULUAN}

Perilaku konsumen adalah studi tentang bagaimana individu, kelompok, dan organisasi memilih, membeli, menggunakan, dan bagaimana barang, jasa, ide, atau pengalaman untuk memuaskan kebutuhan dan keinginan mereka (Kotler dan Keller, 2009). Kualitas pelayanan adalah upaya pemenuhan kebutuhan dan keinginan pelanggan serta ketepatan penyampaiannya untuk mengimbangi harapan pelanggan (Tjiptono, 2014). Indikator yang digunakan untuk mengukur kualitas pelayanan antara lain: keandalan (reliability), ketanggapan (responsiveness), perhatian (empathy), bukti fisik (tangibles), dan jaminan (assurance) (Zeithaml et.al dalam Kotler (2006)). Apabila kualitas pelayanan yang diberikan oleh pihak penyedia jasa baik, maka akan dapat dicapai kepuasan konsumen.

Kepuasan konsumen menunjukkan sikap keseluruhan konsumen terhadap suatu produk barang atau jasa setelah menggunakan atau mengkonsumsi produk tersebut, (Suprapti, 2010). Lima dimensi utama untuk mengukur kepuasan pelanggan, yaitu: Price (Harga), Service Quality (Kualitas Pelayanan), Product Quality (Kualitas Produk), Emotional Factor (Faktor
Emosional) dan Efficiency (Kemudahan) (Irawan, 2007). Dari kelima dimensi tersebut, dalam penelitian ini lebih difokuskan dalam dimensi kualitas pelayanan. Karena berdasarkan informasi yang diperoleh peneliti, permasalahan yang paling banyak di lokasi penelitian adalah mengenai kualitas pelayanan.

Rumah Sakit Bangli Medika Canti merupakan salah satu rumah sakit di Kabupaten Bangli yang menyediakan jasa pelayanan kesehatan. Dalam menjalankan aktivitas pelayanannya, Rumah Sakit Bangli Medika Canti juga menemui beberapa masalah terkait kualitas pelayanan. Menurut pendapat konsumen, permasalahan yang ditemui di Rumah Sakit Bangli Medika Canti diantaranya: petugas yang kurang terampil dan cekatan dalam menangani pasien, antrean pendaftaran lama hingga hasil pemeriksaan yang lama, lahan parkir yang kurang memadai, belum tersedianya ATM (Anjungan Tunai Mandiri/Automated Teller Machine), ketersediaan kursi di ruang tunggu yang kurang serta penampilan perawat dan petugas yang terkadang kurang rapi. Berikut ini adalah data jumlah pasien rawat inap Rumah Sakit Bangli Medika Canti Tahun 2017 dan 2018. 
Tabel 1

Data Jumlah Pasien Rawat Inap Rumah Sakit Bangli Medika Canti Tahun 2017 Dan 2018

\begin{tabular}{|c|c|c|c|c|c|}
\hline \multirow[t]{2}{*}{ Bulan } & \multicolumn{2}{|c|}{$\begin{array}{l}\text { Jumlah } \\
\text { Pasien }\end{array}$} & \multirow[t]{2}{*}{ Target } & \multicolumn{2}{|c|}{$\begin{array}{c}\text { Persentase } \\
\text { Pencapaian } \\
(\%)\end{array}$} \\
\hline & 2017 & 2018 & & 2017 & 2018 \\
\hline Januari & 207 & 237 & 350 & 59,14 & 67,71 \\
\hline Februari & 146 & 247 & 350 & 41,71 & 70,57 \\
\hline Maret & 199 & 258 & 350 & 56,86 & 73,71 \\
\hline April & 193 & 294 & 350 & 55,14 & 84,00 \\
\hline Mei & 190 & 262 & 350 & 54,29 & 74,86 \\
\hline Juni & 206 & 313 & 350 & 58,86 & 89,43 \\
\hline Juli & 185 & 416 & 350 & 52,86 & $\begin{array}{c}118,8 \\
6\end{array}$ \\
\hline Agustus & 186 & 366 & 350 & 53,14 & $\begin{array}{c}104,5 \\
7\end{array}$ \\
\hline September & 256 & 397 & 350 & 73,14 & $\begin{array}{c}113,4 \\
2\end{array}$ \\
\hline Oktober & 226 & 457 & 350 & 64,57 & $\begin{array}{c}130,5 \\
7\end{array}$ \\
\hline November & 252 & 405 & 350 & 72,00 & $\begin{array}{c}115,7 \\
1\end{array}$ \\
\hline Desember & 270 & 420 & 350 & 77,14 & $\begin{array}{c}120,0 \\
0\end{array}$ \\
\hline Total & 2.516 & 4.072 & 4.200 & & \\
\hline $\begin{array}{l}\text { Rata-rata } \\
\text { per bulan }\end{array}$ & 210 & 339 & 350 & $\mathbf{5 9 , 9 0}$ & 96,95 \\
\hline
\end{tabular}

Berdasarkan data pasien rawat inap Rumah Sakit Bangli Medika Canti tahun 2017 dan tahun 2018 pada Tabel 1, diperoleh informasi jumlah pasien rawat inap pada tahun 2017 adalah sebanyak 210 pasien dan jumlah pasien rawat inap pada tahun 2018 adalah sebanyak 339 pasien. Secara umum jumlah pasien rawat inap Rumah Sakit Bangli Medika Canti mengalami peningkatan, akan tetapi belum memenuhi target yang ditentukan oleh pihak rumah sakit, yaitu 350 pasien per bulan. Pencapaian pada tahun 2017 sebesar 59,90\% dan pencapaian pada tahun 2018 sebesar 96,95\%. Selain itu, pihak Rumah Sakit
Bangli Medika Canti juga menyatakan bahwa sebelumnya belum pernah dilakukan pengukuran tingkat kepuasan pasien rawat inap Rumah Sakit Bangli Medika Canti, sehingga belum diketahui bagaimana tingkat kepuasan pasien rawat inap di Rumah Sakit Bangli Medika Canti. Adanya permasalahan mengenai kualitas pelayanan seperti yang telah dikemukakan sebelumnya pada pasien rawat inap Rumah Sakit Bangli Medika Canti maka sangat layak dalam penelitian ini diteliti lebih jauh mengenai tingkat kepuasan pasien rawat inap Rumah Sakit Bangli Medika Canti. Penelitian ini bertujuan untuk 
mengetahui tingkat kepuasan pasien rawat inap Rumah Sakit Bangli Medika Canti ditinjau dari kualitas pelayanan dan untuk mengetahui atribut yang menjadi prioritas untuk diperbaiki pada pasien rawat inap Rumah Sakit Bangli Medika Canti.

Desain penelitian ini termasuk dalam penelitian kuantitatif, yaitu penelitian yang mana analisis datanya bersifat kuantitatif/statistik untuk mengetahui keberadaan hubungan suatu variabel penelitian dan kaitannya dengan variabel lainnya. Populasi dalam penelitian ini adalah pasien rawat inap Rumah Sakit Bangli Medika Canti tahun 2018 sebanyak 4.072 pasien. Penentuan sampel menggunakan Rumus Slovin dan diperoleh jumlah sampel sebanyak 98 pasien rawat inap Rumah Sakit Bangli Medika Canti sebagai responden penelitian. Teknik pengumpulan data dalam penelitian ini dilakukan dengan observasi, wawancara, kuesioner dan studi dokumentasi. Setiap jawaban kuesioner mempunyai bobot atau skor

Desain penelitian ini termasuk dalam penelitian kuantitatif, yaitu penelitian yang mana analisis datanya bersifat kuantitatif/statistik untuk mengetahui keberadaan hubungan suatu variabel penelitian dan kaitannya dengan variabel lainnya. Populasi dalam penelitian ini adalah pasien rawat inap Rumah Sakit Bangli Medika Canti tahun 2018 sebanyak 4.072 pasien. Penentuan sampel menggunakan Rumus Slovin dan diperoleh jumlah sampel sebanyak 98 pasien rawat inap Rumah Sakit Bangli Medika Canti sebagai responden penelitian. Teknik pengumpulan data dalam penelitian ini dilakukan dengan observasi, wawancara, kuesioner dan studi dokumentasi. Setiap jawaban nilai dengan skala Likert sebagai berikut: STP (Sangat Tidak Puas) dan STP (Sangat Tidak Penting) $=$ skor $1, \mathrm{TP}$ (Tidak Puas) dan TP (Tidak Penting) $=$ skor 2, CP (Cukup Puas) dan CP (Cukup Penting) $=$ skor $3, \mathrm{P}$ (Puas) dan $\mathrm{P}$ (Penting) $=$ skor 4 dan SP (Sangat Puas) dan SP $($ Sangat Penting $)=$ skor 5. Teknik analisis data dalam penelitian ini menggunakan pendekatan kuantitatif yaitu:

\section{Indeks Kepuasan Konsumen atau Customer Satisfaction Index (CSI)}

CSI ini diukur dengan menggunakan pembobotan rataan tingkat kepentingan dan tingkat kepuasan dari masing-masing atribut

Langkah-langkah untuk menghitung CSI antara lain:

Menentukan Mean Importance Score $(M I S)$ :

$$
M I S=\frac{\sum_{i=1}^{n} Y_{i}}{\mathrm{n}}
$$

kuesioner mempunyai bobot atau skor nilai dengan skala Likert sebagai berikut: STP (Sangat Tidak Puas) dan STP $($ Sangat Tidak Penting $)=$ skor $1, \mathrm{TP}$ (Tidak Puas) dan TP (Tidak Penting) $=$ skor 2, CP (Cukup Puas) dan CP (Cukup Penting) $=$ skor $3, \mathrm{P}$ (Puas) dan $\mathrm{P}$ (Penting) $=$ skor 4 dan SP (Sangat Puas) dan SP $($ Sangat Penting $)=$ skor 5. Teknik analisis data dalam penelitian ini menggunakan pendekatan kuantitatif yaitu:

Indeks Kepuasan Konsumen atau Customer Satisfaction Index (CSI) 
CSI ini diukur dengan $\quad \Sigma M I S_{i}=$ Jumlah $M I S$ seluruh variabel menggunakan pembobotan rataan tingkat kepentingan dan tingkat kepuasan dari masing-masing atribut

Menentukan Mean Satisfaction Score $(M S S)$ :

Langkah-langkah untuk menghitung CSI antara lain:

Menentukan Mean Importance Score $(M I S)$ :

$$
M I S=\frac{\sum_{i=1}^{n} Y_{i}}{\mathrm{n}}
$$

Dimana :

$\mathrm{n}:$ Jumlah responden

Yi : Nilai Kepentingan Atribut ke-i

Menentukan Weight Factors (WF):

$$
W F=\frac{M I S_{i}}{\sum_{i=1}^{p} M I S_{i}} \times 100 \%
$$

Dimana :

$M I S_{i=} M I S$ per variabel

$$
M S S=\frac{\sum_{i=1}^{n} X_{i}}{\mathrm{n}}
$$

Dimana :

$\mathrm{n}$ : Jumlah responden

Xi : Nilai Kepentingan Atribut ke-i

Menentukan Weight Score (WS):

$$
W S_{i}=W F_{i} x M S S_{i}
$$

Menghitung Customer Satisfaction Index (CSI):

$$
C S I=\frac{\sum_{i=1}^{p} W S_{i}}{H S} \times 100 \%
$$

Dimana : HS (Highest Scale) = skala maksimum yang digunakan (5)

Hasil analisis CSI dikategorikan ke dalam kriteria CSI sebagai berikut :

Tabel 2

Kriteria Tingkat Kepuasan

\begin{tabular}{|c|c|c|}
\hline No & Nilai CSI (\%) & Kriteria \\
\hline $\mathbf{1}$ & $80 \%<\mathrm{CSI} \leq 100 \%$ & Sangat Puas \\
\hline $\mathbf{2}$ & $60 \%<\mathrm{CSI} \leq 80 \%$ & Puas \\
\hline $\mathbf{3}$ & $40 \%<\mathrm{CSI} \leq 60 \%$ & Cukup Puas \\
\hline $\mathbf{4}$ & $20 \%<\mathrm{CSI} \leq 40 \%$ & Kurang Puas \\
\hline $\mathbf{5}$ & $0 \%<\mathrm{CSI} \leq 20 \%$ & Tidak Puas \\
\hline
\end{tabular}




\section{Analisis Tingkat Kepentingan Kinerja atau Importance Performance Analysis (IPA)}

Langkah-langkahnya adalah dengan menentukan tingkat kesesuaian kepentingan-kepuasan dengan rumus sebagai berikut:

$$
T k_{i}=\frac{\bar{X}_{i}}{\bar{Y}_{i}} x 100 \%
$$

dimana :

$\mathrm{Tk}_{\mathrm{i}}=$ Tingkat kesesuaian responden.

$\bar{X}_{L}=$ Skor rata-rata tingkat kepuasan

$\bar{Y}_{l}=$ Skor rata-rata tingkat kepentingan

Selanjutnya melakukan analisis

kuadran dengan rumus sebagai berikut:

$$
\overline{\mathrm{X}}=\frac{\sum \mathrm{X}_{\mathrm{i}}}{\mathrm{n}} \quad \overline{\mathrm{Y}}=\frac{\sum \mathrm{Y}_{\mathrm{i}}}{\mathrm{n}}
$$

dimana :

$\overline{\mathrm{X}}=$ Skor rata-rata kepuasan / performance.

$\overline{\mathrm{Y}}=$ Skor rata-rata kepentingan / importance. $\mathrm{n}=$ Jumlah responden.

Kemudian menentukan rata-rata dari rata-rata seluruh atribut kepentingan dan kepuasan dengan rumus sebagai berikut:

$$
\overline{\bar{X}}=\frac{\sum_{\mathrm{i}=1}^{\mathrm{N}} \overline{\mathrm{X}_{\mathrm{i}}}}{k} \quad \overline{\bar{Y}}=\frac{\sum_{\mathrm{i}=1}^{\mathrm{N}} \overline{\mathrm{Y}_{\mathrm{i}}}}{k}
$$

dimana :

$\overline{\bar{X}}=$ Rata-rata dari rata-rata skor tingkat kepuasan seluruh atribut.

$\overline{\bar{Y}}=$ Rata-rata dari rata-rata skor tingkat kepentingan seluruh atribut.

$\mathrm{k}=$ Banyaknya atribut yang mempengaruhi kepuasan.

Setelah diperoleh titik potong sumbu $\mathrm{X}$ dan sumbu Y, dapat dimasukkan ke dalam Diagram Cartesius Importance Performance Analysis (IPA) yang terbagi ke dalam empat kuadran yang masing-masing memiliki tingkat prioritas yang berbeda-beda seperti gambar 1 berikut ini.

Gambar 1

Diagram Cartesius Importance-Perfomance Analysis (IPA)

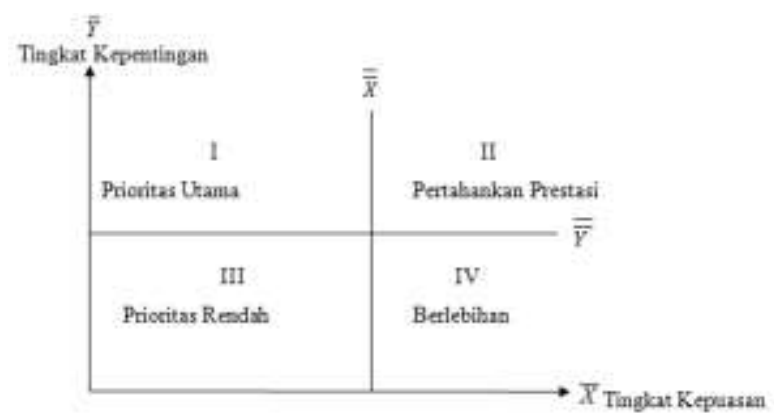

Sumber: Martilla dan James dalam Risabella, 2016.

Keempat kuadran tersebut masingmasing memiliki arti sebagai berikut :

Kuadran I (Prioritas utama): Kuadran ini memuat atribut yang dianggap mempengaruhi kepuasan responden, namun pada kenyataannya atribut-atribut tersebut belum sesuai dengan harapan responden (belum memuaskan).

Kuadran II (Pertahankan prestasi): Kuadran ini menunjukkan atribut yang telah berhasil dilaksanakan perusahaan, untuk itu wajib dipertahankan. Dianggap 
sangat penting dan sangat memuaskan. Kuadran III (Prioritas rendah): Atributatribut yang terdapat dalam kuadran ini dianggap kurang penting oleh responden dan pada kenyataannya pelayanan dianggap tidak terlalu istimewa. Kuadran IV (Berlebihan): Kuadran ini menunjukkan atribut yang kurang penting pengaruhnya bagi responden tetapi layanan yang dirasakan terlalu berlebihan .

\section{HASIL PENELITIAN}

\section{Customer Satisfaction Index (CSI)}

Customer Satisfaction Index (CSI) atau Indeks Kepuasan Konsumen dalah metode yang digunakan untuk mengetahui tingkat kepuasan konsumen secara menyeluruh dengan cara melihat tingkat kepentingan dari atribut-atribut produk atau jasa tersebut.

Langkah-langkah yang dilakukan dalam menghitung CSI adalah menentukan Mean Importance Score (MIS), Weight Factors (WF), Mean Satisfaction Score (MSS), Weight Score (WS) dan menentukan Customer Satisfaction Index (CSI) (Hill dalam Amanda, 2016). Hasil perhitungan MIS, WF, MSS dan WF dapat dilihat pada tabel 3.

Tabel 3

Hasil Perhitungan MIS, WF, MSS dan WS

\begin{tabular}{|c|c|c|c|c|}
\hline No. & MIS & WF & MSS & WS \\
\hline 1 & 4,20 & 5,08 & 4,01 & 20,22 \\
\hline 2 & 3,92 & 4,91 & 3,89 & 19,44 \\
\hline 3 & 4,06 & 5,06 & 3,70 & 19,72 \\
\hline 4 & 4,09 & 4,96 & 3,95 & 18,34 \\
\hline 5 & 4,16 & 5,02 & 3,98 & 20,13 \\
\hline 6 & 4,14 & 5,06 & 3,89 & 19,67 \\
\hline 7 & 4,04 & 5,09 & 3,86 & 20,47 \\
\hline 8 & 3,98 & 4,95 & 3,81 & 19,54 \\
\hline 9 & 4,04 & 4,99 & 3,85 & 19,73 \\
\hline 10 & 4,06 & 4,93 & 3,94 & 19,04 \\
\hline 11 & 4,17 & 4,79 & 3,90 & 18,62 \\
\hline 12 & 4,02 & 4,96 & 3,96 & 19,53 \\
\hline 13 & 4,17 & 5,09 & 3,99 & 20,32 \\
\hline 14 & 4,17 & 5,13 & 4,02 & 20,57 \\
\hline 15 & 4,14 & 5,04 & 3,90 & 19,47 \\
\hline
\end{tabular}




\begin{tabular}{|c|c|c|c|c|}
\hline 16 & 4,11 & 4,93 & 4,01 & 18,99 \\
\hline 17 & 4,04 & 4,93 & 3,98 & 19,64 \\
\hline No. & MIS & WF & MSS & WS \\
\hline 18 & 4,20 & 5,09 & 3,89 & 19,86 \\
\hline 19 & 4,05 & 4,86 & 3,95 & 18,52 \\
\hline 20 & 4,13 & 5,13 & 3,86 & 19,95 \\
\hline Jumlah & $\mathbf{8 1 , 8 9}$ & $\mathbf{1 0 0 , 0 0}$ & $\mathbf{7 8 , 3 4}$ & $\mathbf{3 9 1 , 7 7}$ \\
\hline
\end{tabular}

Sumber: Olah data SPSS 23.0 for Windows, 2019

Berdasarkan Tabel 3 dapat dihitung besarnya CSI sebagai berikut:

$$
\begin{aligned}
& C S I=\frac{\sum_{i=1}^{p} W S_{i}}{H S} \times 100 \% \\
& C S I=\frac{391,77}{5} \times 100 \% \\
& C S I=78,35 \times 100 \% \\
& C S I=78,35 \%
\end{aligned}
$$

Jadi diperoleh nilai CSI sebesar $78,35 \%$, yang berarti tingkat kepuasan pasien rawat inap Rumah Sakit Bangli Medika Canti berada pada rentang $60 \%$ $<$ CSI $\leq 80 \%$ yang berarti tingkat kepuasan pasien rawat inap Rumah Sakit Bangli Medika Canti berada pada kriteria puas.

Sementara itu, berdasarkan nilai Weight Score (WS) masing-masing atribut, dapat diketahui atribut-atribut yang memiliki nilai Weight Score (WS) terendah dari seluruh atribut yang menjadi perhatian utama untuk diperbaiki jika ditinjau dari hasil analisis Customer Satisfaction Index (CSI) atau Indeks Kepuasan Konsumen sebagai berikut:

Atribut Tangibles4 : Lahan Parkir
Atribut Assurance3 : Petugas memiliki pengetahuan luas

Atribut Reliability3 : Pelayanan efisien (tidak berbelit-belit)

Atribut Responsiveness 4 : Tanggap dalam menangani keluhan

Sedangkan atribut-atribut yang memiliki nilai Weight Score (WS) tertinggi dari seluruh atribut yang dinilai telah memuaskan konsumen, ditinjau dari hasil analisis Customer Satisfaction Index (CSI) atau Indeks Kepuasan Konsumen adalah sebagai berikut:

Atribut Responsiveness2 : Tanggap dalam memberi informasi

Atribut Emphaty3: Petugas ramah

Atribut Responsiveness 1: Petugas melayani dengan tanggap

Atribut Tangibles1: Ruang Tunggu

\section{Importance Performance Analysis (IPA)}

Importance Performance Analysis atau analisis tingkat kepentingan dan kinerja pelanggan digunakan untuk memetakan tingkat kepuasan pelanggan terhadap kinerja perusahaan. 
Penggunaan metode ImportancePerformance Analysis adalah dalam mengukur tingkat kepuasan pelayanan jasa yang masuk pada kuadran-kuadran pada peta diagram kartesius ImportancePerformance Analysis (Rangkuti dalam Nugraha dkk, 2014). Langkah-langkah yang dilkakukan dalam menentukan IPA antara lain: menentukan tingkat kesesuaian (TKi) dengan cara membagi rata-rata tingkat kepuasan (Xi) dengan rata-rata tingkat kepentingan (Yi) dan melakukan analisis kuadran. Hasil perhitungan tingkat kesesuaian kepentingan-kepuasan dapat dilihat pada tabel 4

Tabel 4

Hasil Perhitungan Tki

\begin{tabular}{|c|c|c|c|}
\hline No. Atribut & $\mathbf{X}_{\mathbf{i}}$ & $\bar{Y}_{\mathbf{i}}$ & Tki (\%) \\
\hline 1 & 4,01 & 4,20 & 95,40 \\
\hline 2 & 3,89 & 3,92 & 98,00 \\
\hline 3 & 3,70 & 4,06 & 91,20 \\
\hline 4 & 3,95 & 4,09 & 96,50 \\
\hline 5 & 3,98 & 4,16 & 95,60 \\
\hline 6 & 3,89 & 4,14 & 93,80 \\
\hline 7 & 3,86 & 4,04 & 95,50 \\
\hline 8 & 3,81 & 3,98 & 98,00 \\
\hline 9 & 3,85 & 4,04 & 98,20 \\
\hline 10 & 3,94 & 4,06 & 97,00 \\
\hline 11 & 3,90 & 4,17 & 97,10 \\
\hline 12 & 3,96 & 4,02 & 98,50 \\
\hline 13 & 3,99 & 4,17 & 95,60 \\
\hline 14 & 4,02 & 4,17 & 96,30 \\
\hline 15 & 3,90 & 4,14 & 94,10 \\
\hline 16 & 4,01 & 4,11 & 97,50 \\
\hline 17 & 3,98 & 4,04 & 99,30 \\
\hline 18 & 3,89 & 4,20 & 94,30 \\
\hline 19 & 3,95 & 4,05 & 97,50 \\
\hline 20 & 3,86 & 4,13 & 94,60 \\
\hline Jumlah & 78,34 & 81,89 & 95,66 \\
\hline
\end{tabular}

Sumber: Olah data SPSS 23.0 for Windows, 2019. 
Berdasarkan tabel 4, diperoleh informasi lima atribut yang memiliki tingkat kesesuaian paling rendah adalah sebagai berikut:

Atribut $3=91,20:$ Fasilitas penunjang

Atribut $6=93,80:$ Petugas memberikan perhatian secara individu

Atribut $15=94,10$ : Melayani tepat waktu

Atribut $18=94,30$ : Merasa aman saat menerima pelayanan

Atribut $20=4,60$ : Menjamin memberi kepercayaan kepada konsumen

Atribut yang menjadi prioritas untuk diperbaiki dalam kualitas pelayanan pasien rawat inap Rumah Sakit Bangli Medika Canti adalah atribut fasilitas penunjang, karena memiliki tingkat kesesuaian paling rendah. Selanjutnya dilakukan analisis kuadran. Sumbu X merupakan rataan dari skor tingkat kepuasan pasien per atribut pertanyaan, dan sumbu Y merupakan rataan skor dari tingkat kepentingan pasien per atribut pertanyaan yang dihitung dengan rumus sebagai berikut:

Mencari titik potong sumbu $\mathrm{X}$ :

$$
\begin{aligned}
& \overline{\bar{X}}=\frac{\sum_{\mathrm{i}=1}^{\mathrm{N}} \overline{\mathrm{X}_{\mathrm{i}}}}{k} \\
& \overline{\bar{X}}=\frac{78,34}{20}
\end{aligned}
$$

$$
\overline{\bar{X}}=3,92
$$

Mencari titik potong sumbu Y:

$$
\begin{aligned}
\overline{\bar{Y}} & =\frac{\sum_{\mathrm{i}=1}^{\mathrm{N}} \overline{Y_{\mathrm{i}}}}{k} \\
\overline{\bar{Y}} & =\frac{81,89}{20} \\
\overline{\bar{Y}} & =4,09
\end{aligned}
$$

Nilai $\overline{\bar{X}}$ memotong tegak lurus pada sumbu horizontal, yakni sumbu yang mencerminkan kinerja atribut (X) atau kepuasan pelanggan. Sedangkan nilai $\overline{\bar{Y}}$ memotong tegak lurus pada sumbu vertikal, yakni sumbu yang mencerminkan kepentingan atribut (Y) atau harapan pelanggan.Setelah diperoleh titik potong sumbu $\mathrm{X}$ dan sumbu Y, maka dapat digambarkan Diagram Kartesius ImportancePerformance Analysis sebagai berikut:Langkah-langkahnya adalah dengan menentukan tingkat kesesuaian kepentingan-kepuasan dengan rumus sebagai berikut:

Setelah diperoleh titik potong sumbu $\mathrm{X}$ dan sumbu Y, dapat dimasukkan ke dalam Diagram Cartesius Importance Performance Analysis (IPA) yang terbagi ke dalam empat kuadran yang masing-masing memiliki tingkat prioritas yang berbeda-beda seperti gambar 1 berikut ini. 
Gambar 2

Diagram Cartesius Importance-Perfomance Analysis (IPA) Pada Pasien Rawat Inap

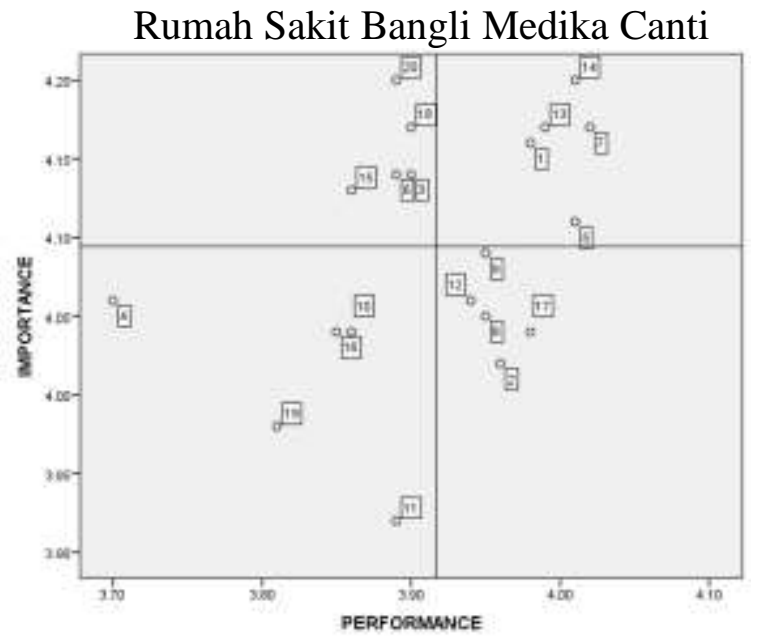

Sumber: Olah data SPSS 23.0 for Windows, 2019.

Berdasarkan Gambar 2, diperoleh informasi atribut-atribut yang masuk ke dalam kuadran I, II, III dan IV sebagai berikut:

Kuadran I (Prioritas utama)

Atribut-atribut yang berada pada kuadran ini dianggap sangat penting oleh pelanggan tetapi tingkat kepuasan pasien belum tercapai, hal ini diketahui dari tingkat kepuasan pasien yang diperoleh lebih rendah dari tingkat kepentingannya. Atribut-atribut ini prioritas utama untuk segera dilakukan perbaikan oleh perusahaan.

Atribut 3 : Fasilitas penunjang

Atribut 6: Petugas memberikan perhatian secara individu

Atribut 15: Melayani tepat waktu

Atribut 18: Merasa aman saat menerima pelayanan

Atribut 20 : Menjamin memberi Kepercayaan kepada konsumen

Kuadran II (Pertahankan prestasi)
Atribut-atribut yang berada pada kuadran ini dianggap sangat penting oleh pelanggan dan kinerja pelayanannya sangat memuaskan. Pihak Rumah Sakit Bangli Medika Canti harus mempertahankan kinerja atribut-atribut kualitas pelayanan yang berada pada kuadran ini.

Atribut 1: Ruang tunggu

Atribut 7: Petugas ramah

Atribut 5 : Memperoleh informasi

Dengan mudah

Atribut 13 : Petugas melayani dengan tanggap

Atribut 14 : Tanggap dalam memberi informasi

Kuadran III (Prioritas rendah)

Atribut-atribut pada kuadran ini dianggap tidak terlalu penting oleh pelanggan dan pelayanannya dianggap tidak terlalu istimewa.

Atribut 4 : Lahan parkir

Atribut 10 : Petugas menguasai tugas

Atribut 11 : Pelayanan efesien (tidak berbelit-belit)

Atribut 16 : Tanggap dalam menangani 
keluhan

Atribut 19 : Petugas memiliki pengetahuan luas

Kuadran IV (Berlebihan)

Atribut-atribut yang berada pada kuadran ini dianggap tidak terlalu penting oleh pelanggan tetapi pelayanannya memuaskan. Kuadran ini menunjukkan atribut yang kurang penting pengaruhnya bagi responden tetapi layanan yang dirasakan terlalu berlebihan. Tidak dianjurkan melakukan peningkatan layanan terhadap atribut yang masuk dalam kuadran karena hanya menyebabkan pemborosan sumber daya.

Atribut 2 : Penampilan pegawai

Atribut 8 : Melayani pasien tanpa

Membedakan status

Atribut 9: Petugas teliti dalam memberikan pelayanan

Atribut 12 : Petugas melayani dengan cepat

Atribut 17 : Menjamin kerahasiaan data

Atribut yang termasuk ke dalam Kuadran I, yaitu atribut fasilitas penunjang yang menjadi prioritas untuk diperbaiki, karena rata-rata tingkat kepuasannya lebih rendah dari pada ratarata dari rata-rata tingkat kepuasan seluruh atribut dan rata-rata tingkat kepentingannya lebih rendah dari pada rata-rata dari rata-rata tingkat kepentingan seluruh atribut.

\section{PENUTUP \\ KESIMPULAN}

Berdasarkan hasil analisis data dan pembahasan, maka didapat kesimpulan hasil penelitian pada pasien rawat inap Rumah Sakit Bangli Medika Canti. Tingkat kepuasan pasien rawat inap Rumah Sakit Bangli Medika Canti berada pada kriteria Puas. Dan atribut yang menjadi prioritas untuk diperbaiki dalam kualitas pelayanan pada pasien rawat inap Rumah Sakit Bangli Medika Canti adalah atribut yang memiliki nilai tingkat kesesuaian paling rendah, yaitu atribut fasilitas penunjang.

\section{SARAN-SARAN}

Dalam usaha meningkatkan kepuasan konsumen pada pasien rawat inap Rumah Sakit Bangli Medika Canti, disarankan bagi pihak Rumah Sakit Bangli Medika Canti. Mempertahankan dan meningkatkan kepuasan konsumen dengan mempertahankan kinerja atribut yang telah memuaskan dan fokus untuk memperbaiki atribut yang menjadi prioritas untuk diperbaiki yaitu atribut fasilitas penunjang.

Hal yang dapat dilakukan adalah dengan memperbaiki kondisi fasilitas penunjang, antara lain dengan menambah dan atau memperbaiki kondisi fasilitas penunjang seperti toilet, menyediakan ATM (Anjungan Tunai Mandiri/Automated Teller Machine), menyediakan kursi yang lebih banyak di ruang tunggu, memperjelas ramburambu petunjuk masing-masing lantai (ruangan) dan menambah fasilitas free wifi.

Selain itu, pihak Rumah Sakit Bangli Medika Canti disarankan untuk melakukan penyebaran kuesioner secara berkala untuk mengetahui tingkat kepuasan konsumennya, sehingga pasien mempunyai tempat untuk menuangkan kritik dan saran demi meningkatkan kualitas pelayanan pada pasien rawat inap Rumah Sakit Bangli Medika Canti.

\section{DAFTAR PUSTAKA}

Akbar, Usman. (2006). Metodologi Penelitian Sosial. Jakarta: Bumi Aksara. 
Amanda, Tasya. (2016). Analisis Tingkat Kepuasan Konsumen Restoran Waroeng Hotplate Odon Cibanteng, Bogor, Jawa Barat. Bogor: Fakultas Ekonomi Dan Manajemen Institut Pertanian Bogor.

Anissa, Valentina. (2012). Analisis Pengaruh Kualitas Pelayanan Terhadap Kepuasan Konsumen (Studi Pada Pasien Poliklinik Rawat Jalan Rumah Sakit Dr. Cipto Mangunkusumo). Semarang: Fakultas Ekonomika Dan Bisnis Universitas Diponegoro.

Irawan, Hadi. (2007). 10 Prinsip Kepuasan Pelanggan. Paradigma baru merebut hati pelanggan untuk memenangkan persaingan. Jakarta: Gramedia.

Junaidin. (2016). Analisis Tingkat Kepuasan Pasien Rawat Inap Rumah Sakit Umum Daerah Bima Provinsi NTB Tahun 2016. Nusa Tenggara Barat: STIKES Yahya Bima.

Kotler, Philip. (2006). Manajemen Pemasaran Jilid 1. Edisi Milenium. Jakarta : Prehallindo.

Kotler, Philip. Keller, KL. (2009). Manajemen Pemasaran, Jilid 1. Edisi 12. Jakarta : Indeks.

Kurniati, Eka. Silvia, Evanila. Efendi, Zulman. (2016). Analisis Kepuasan Konsumen Terhadap Kue Baytat Bengkulu. Jurnal Teknologi Dan Industri Pertanian Indonesia. Vol 08, No 02.

Marissa, Yossy. (2016). Analisa Tingkat Kepuasan Penumpang Terhadap Pelayanan Pelabuhan Tanjung ApiApi. Palembang: Fakultas Teknik, Universitas Sriwijaya.

Noor, Juliansyah. (2011). Metodologi Penelitian. Jakarta: Kencana.
Nugraha, Rizal. Harsono, Ambar. Adianto, Hari. (2014). Usulan Peningkatan Kualitas Pelayanan Jasa pada Bengkel "X" Berdasarkan Hasil Matrix Importance Performance Analysis (Studi Kasus di Bengkel AHASS PD. Sumber Motor Karawang). Bandung : Jurusan Tenkik Industri Institut Teknologi Nasional Bandung.

Nugroho, Dwi. (2013). Analisis Tingkat Loyalitas Konsumen Terhadap Kartu simPATI (Studi Kasus Pada Pengunjung GraPARI Telkomsel Surakarta). Surakarta: Fakultas Ekonomi Dan Bisnis Universitas Muhammadiyah Surakarta

Pari, Fauzie. (2017). Analisis Kepuasan Konsumen Terhadap Kualitas Pelayanan Di Chicken Corner 7 Tangerang. Bogor: Fakultas Ekonomi Dan Manajemen Institut Pertanian Bogor.

Purwanto, Asih. (2008). Pengaruh Kualitas Produk, Promosi dan Desain Terhadap Keputusan Pembelian Kendaraan Bermotor Yamaha Mio. Surakarta: Fakultas Ekonomi Universitas Muhammadiyah

Risabella. (2016). Analisis Kepuasan Pelanggan Terhadap Pelayanan Jasa Kesehatan (Studi Kasus Rumah Sakit Citra Medika Depok). Bogor: Fakultas Matematika Dan Ilmu Pengetahuan Alam Institut Pertanian Bogor.

Sugiyono. (2015). Metode Penelitian dan Pengembangan Research and Development. Bandung: Alfabeta.

Sugiyono. (2016). Metode Penelitian Pendidikan Pendekatan Kuantitatif,Kualitatif Dan $R \& D$. Bandung: Alfabeta.

Suprapti,N.W.S. (2010). Perilaku Konsumen : Pemahaman Dasar dan Aplikasinya dalam Strategi 
Pemasaran. Bali: Universitas Udayana Bali.

Swastha, Basu. Irawan. (2003). Manajemen Pemasaran Modern. Yogyakarta: Liberty Yogyakarta.

Tjiptono, Fandy. (2014). Pemasaran Jasa. Yogyakarta: Andi.

Wardhani, Ayu. (2015). Kualitas Pelayanan di Rumah Sakit Umum Daerah Syekh Yusuf Gowa. Makassar: Fakultas Ilmu Sosial dan Ilmu Politik Universitas Hasanuddin.

Yamit, Zulian. (2005). Manajemen Kualitas Produk dan Jasa. Jakarta: Ekonisia. 